\title{
Correction: Deficiency of calcium/calmodulin-dependent serine protein kinase disrupts the excitatory-inhibitory balance of synapses by downregulating GluN2B
}

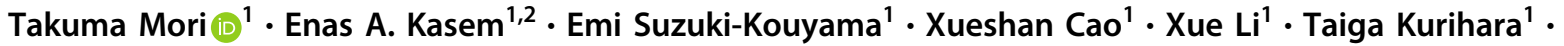 \\ Takeshi Uemura ${ }^{1,3,4} \cdot$ Toru Yanagawa $\mathbb{1}^{5} \cdot$ Katsuhiko Tabuchi ${ }^{1,3,6}$
}

Published online: 31 January 2019

(c) The Author(s) 2019. This article is published with open access

\section{Correction to: Molecular Psychiatry; https://doi.org/10.1038/s41380-018-0338-4; published online 4 January 2019}

This article was originally published under standard licence, but has now been made available under a [CC BY 4.0] license. The PDF and HTML versions of the paper have been modified accordingly.

These authors contributed equally: Takuma Mori, Enas A. Kasem.

Katsuhiko Tabuchi

ktabuchi@shinshu-u.ac.jp

1 Department of Molecular and Cellular Physiology, Institute of Medicine, Academic Assembly, Shinshu University, 390-8621 Nagano, Japan

2 Department of Zoology, Faculty of Science, Kafr Elsheikh University, 33511 Kafr Elsheihk, Egypt

3 Institute for Biomedical Sciences, Interdisciplinary Cluster for Cutting Edge Research, Shinshu University, 390-8621

Nagano, Japan

4 CREST, JST, 332-0012 Saitama, Japan

5 Department of Oral and Maxillofacial Surgery, Faculty of Medicine, University of Tsukuba, 305-8575 Ibaraki, Japan

6 PRESTO, JST, 332-0012 Saitama, Japan
Open Access This article is licensed under a Creative Commons Attribution 4.0 International License, which permits use, sharing, adaptation, distribution and reproduction in any medium or format, as long as you give appropriate credit to the original author(s) and the source, provide a link to the Creative Commons license, and indicate if changes were made. The images or other third party material in this article are included in the article's Creative Commons license, unless indicated otherwise in a credit line to the material. If material is not included in the article's Creative Commons license and your intended use is not permitted by statutory regulation or exceeds the permitted use, you will need to obtain permission directly from the copyright holder. To view a copy of this license, visit http://creativecommons. org/licenses/by/4.0/. 